\title{
Peran Elit Desa Dalam Pengembangan Wellness Tourism \\ Di Desa Adat Bindu, Desa Mekar Bhuana, Kecamatan Abiansemal, Kebupaten Badung
}

Ni Wayan Gita Sadhana Savitri a, 1,I Nyoman Sukma Arida a, 2

1 gitasadhana07@gmail.com, ${ }^{2}$ sukma_arida@unud.ac.id

a Program Studi Sarjana Destinasi Pariwisata, Fakultas Pariwisata,Universitas Udayana, Jl. Dr. R. Goris No 7, Denpasar, Bali 80232 Indonesia

\section{Abstract}

Bindu Village is located at Badung district, which has potency to develop the wellness tourism. Development wellness tourism at Bindu village involves the elite people. The purpose of this study was to identify tourist attractions and the role of elite people in developing wellness tourism at Bindu village. Data collection techniques conducted in this study are observation techniques, interview techniques and documentary techniques. The determination technique of informant uses the purposive sampling technique. Data analysis technique used is qualitative data analysis technique. The results of the discussion that can be concluded is wellness tourism activities by doing healer activities, purification and therapy. Bindu Village has tourism potency such as the natural potential, the cultural potential and the artificial potential. The role of elite people in the development of wellness tourism in Bindu village is carried out by developing those potencies, building tourism facilities and promotions.

Keywords: role, elite people, wellness tourism

\section{PENDAHULUAN}

Pengembangan pariwisata di suatu daerah harus terencana dan tersusun secara maksimal agar potensi yang dimiliki dapat dikembangkan secara optimal. Dalam mengembangkan suatu daerah menjadi sebuah destinasi pariwisata perlu melibatkan berbagai pelaku dalam proses pembangunan pariwisata. Salah satu pelaku yang mempunyai peran penting dalam suatu wilayah ialah elit desa. Dalam suatu daerah yang memiliki potensi pariwisata maka adanya elit desa menjadi salah satu komponen penting dalam pengembangan pariwisata karena elit desa mempunyai kekuasaan dalam menyusun pengembangan pariwisata secara terencana dan terorganisir.

Pembangunan pariwisata yang tersusun dan terencana secara baik akan memberikan manfaat yang optimal. Pembangunan pariwisata yang memperhatikan daya dukung dan target pasar dari destinasi pariwisata penting untuk dilakukan. Pembangunan tersebut mengarah pada pembangunan pariwisata berkelanjutan. Pembangunan pariwisata yang berkelanjutan tidak hanya akan memberikan manfaat kepada para pelaku yang terlibat namun juga memberikan kepuasan bagi wisatawan. Salah satu gaya hidup wisatawan yang perlu diperhatikan yakni kesehatan dan relaksasi. Dengan gaya hidup yang sehat dan mendapatkan ketenangan maka akan memberikan kebahagiaan yang lebih baik. Hal tersebut membawa dampak yang positif terhadap pengembangan wellness tourism di Bali.

Wellness tourism merupakan sebuah produk pariwisata berupa jasa yang dapat dikembangkan atau dikreasikan ragamnya sesuai dengan kondisi sebuah destinasi baik dari sisi sosial maupun lingkungan (Kaspar dalam Mueller dan Kaufmann, 2007). Pengembangan wellness tourism di Bali berhubungan erat dengan kebudayaan Bali yang didasarkan pada ajaran Agama Hindu yang didalamnya terdapat keseimbangan antara tubuh dan jiwa.

Desa Adat Bindu menjadi salah satu desa di Bali yang mulai mengembangkan wellness tourism. Kegiatan yang dilakukan yakni dengan melakukan pengobatan herbal menggunakan tumbuh-tumbuhan maupun rempah-rempah tradisional yang terdapat di Desa Adat Bindu. Kegiatan wellness tourism berkaitan erat dengan kegiatan spiritual yakni dengan dilakukannya healer, pembersihan diri dan terapi guna memberikan ketenangan kepada wisatawan karena mulai dari adanya ketenangan jiwa maka terciptalah kesehatan jasmani. Desa Adat Bindu yang hanya mempunyai satu pintu masuk menjadi suatu keuntungan dari Desa Adat Bindu untuk dikembangkan karena wisatawan akan memperoleh ketenangan saat berada di dalam desa. Selain itu, pengembangan wellness 
tourism di Desa Adat Bindu sangat potensial untuk dikembangkan karena didukung oleh kegiatan spa yang banyak dilakukan wisatawan di Ubud dan didukung letak Desa Adat Bindu yang berada di garis pinggir Kecamatan Ubud.

Namun, kegiatan wellness tourism ini baru beberapa tahun dikembangkan di Desa Adat Bindu dan masih dalam tahap pembangunan fasilitas. Maka dari itu perlu adanya peran dari elit desa dalam pengembangan wellness tourism guna pengembangan yang terencana dan keberlanjutan pengembangan potensi yang ada karena wellness tourism yang dikembangkan di Desa Adat Bindu tergolong tradisional dan unik sehingga berpeluang untuk menarik kunjungan wisatawan.

Tujuan dari dilakukannya penelitian ini adalah mengetahui peran elit desa dalam pengembangan wellness tourism di Desa Adat Bindu sebagai salah satu daya tarik wisata yang ada di Desa Mekar Bhuana, Kecamatan Abiansemal, Kabupaten Badung dalam rangka meningkatkan kesejahteraan masyarakat lokal.

\section{KEPUSTAKAAN}

\subsection{Tinjauan Penelitian Sebelumnya}

Penelitian sebelumnya yang pertama adalah penelitian yang berjudul "Pengaruh Elit Berkuasa Terhadap Pembangunan Desa" yang dilakukan oleh Astuty (2015). Hasil dari penelitian tersebut yakni mengidentifikasi kepemimpinan dan elit berkuasa dalam pembangunan desa. Pada penelitian ini ditemukan bahwa elit berkuasa mempunyai pengaruh yang penting dan signifikan dalam pembangunan desa. Penelitian sebelumnya yang kedua yakni penelitian yang berjudul "trend health and wellness tourism in Indonesia" yang dilakukan oleh Utama (2012). Dalam penelitian tersebut membahas mengenai perkembangan wellness tourism dan saat ini menjadi tren baru yang membuat terjadinya permintaan dengan diimbangi oleh pembuatan berbagai jenis produk wisata.

\subsection{Tinjauan Konsep}

\subsubsection{Peran}

Peran merupakan aspek dinamis dari suatu kedudukan (status). Seseorang dapat dikatakan menjalankan perannya disaat orang tersebut melaksanakan hak serta kewajibannya sesuai dengan kedudukannya (Soerjono Soekanto, 2002).

\subsubsection{Elit Desa}

Elit merupakan seseorang atau kelompok orang yang tergolong unggul pada bidang kegiatannya masing-masing dalam kehidupan masyarakat serta terdiri atas elit yang memerintah dan dihadapmukakan dengan massa yang diperintah (Zeitlin,1981). Selanjutnya Mosca (1939) menjelaskan bahwa elit adalah sejumlah kecil orang-orang yang mampu dalam mengendalikan kekuatankekuatan sosial dalam artian setiap kegiatan sosial yang bermakna sosial berdasarkan pada penguasaan tanah, uang, pendidikan, ilmu dan lain sebagainya. Dalam setiap masyarakat terdapat sedikitnya dua kelas yakni kelas elit yang memimpin dan kelas massa yang dipimpin (Mosca, 1939).

\subsubsection{Pengembangan}

Pengembangan adalah suatu usaha atau strategi yang digunakan dalam memajukan dan memperbaiki serta meningkatkan kondisi kepariwisataan yang terdapat pada suatu daya tarik wisata sehingga menarik dan dapat dikunjungi wisatawan, yang selanjutnya akan mampu memberikan manfaat atau kontribusi kepada masyarakat lokal maupun bagi pemerintah (Paturusi,2001).

\subsubsection{Potensi Pariwisata}

Potensi wisata merupakan segala sumber daya yang ada dalam suatu daerah yang dapat dikembangkan menjadi sebuah atraksi wisata (Pendit, 1999). Potensi wisata dapat dibedakan menjadi 3 yakni : potensi alam, budaya dan buatan manusia.

\subsubsection{Wellness Tourism}

Wellness diartikan sebagai sebuah proses individu membuat pilihan dan terlibat dalam kegiatan hidup yang sehat, yang pada hal ini akan memberikan berdampak positif bagi kesehatan individu itu sendiri (Barre, 2005). Terdapat tujuh dimensi mengenai wellness, yakni : social wellness, physical wellness, emosional wellness, career wellness, intellectual wellness, environmental wellness dan spiritual wellness.

\section{III.METODE PENELITIAN}

Penelitan ini berlokasi di Desa Adat Bindu, Desa Mekar Bhuwana, Kecamatan Abiansemal, Kabupaten Badung. Desa ini memiliki karakteristik desa tradisional 
dengan potensi alam maupun budayanya yang dapat dikemas menjadi produk pariwisata. Kondisi desa yang tenang dan tradisional mendukung dikembangkannya wellness tourism, selain itu didukung juga oleh budaya masyarakat yang masih menggunakan bahanbahan herbal yang ada di pekarangan rumah dengan pengolahan tradisional.

Jenis data dalam penelitian ini menggunakan jenis data kualitatif berupa penjelasan atau deskripsi mengenai potensi wisata dan peran elit desa dalam pengembangan wellness tourism di Desa Adat Bindu. Pada penelitian ini juga menggunakan data kuantitatif berupa data demografis masyarakat Desa Adat Bindu.

Sumber data yang digunakan dalam penelitian ini adalah data primer dan data sekunder. Data primer berupa potensi wisata dan peran elit desa dalam pengembangan wellness tourism di Desa Adat Bindu. Data sekunder dalam penelitian ini berupa data monografi Desa Adat Bindu.

Teknik pengumpulan data dalam penelitian ini menggunakan teknik observasi dengan melakukan pengamatan mengenai keadaan desa. Selanjutnya peneliti melakukan wawancara terhadap elit desa yang pada penelitian ini yakni pengelola Tanah Hyang Healing Centre guna mengetahui upaya yang dilakukan dalam pengembangan wellness tourism di Desa Adat Bindu. Teknik analisis data dalam penelitian ini menggunakan teknik analisis data kualitatif.

\section{IV.HASIL DAN PEMBAHASAN}

\section{1 Gambaran Umum}

Desa Adat Bindu merupakan salah satu dari 5 desa adat yang terdapat di Desa Mekar Bhuana, Kecamatan Abiansemal, Kabupaten Badung. Bindu memiliki berbagai potensi wisata baik alam, budaya maupun buatan, selain itu Bindu juga memiliki potensi dalam pengembangan wellness tourism karena memiliki lahan persawahan yang dipercaya memiliki aura positif dalam penyembuhan jasmani maupun rohani dan didukung oleh masyarakat yang masih menggunakan bahan herbal sebagai obat. Selain itu, suasana desa yang tenang dan masih tradisional serta letaknya yang tidak jauh dari Ubud yakni sekitar 15 menit dan 30 menit dari Kota
Denpasar maka menjadikan Desa Adat Bindu sangat potensial untuk dikembangkan.

\section{2 Potensi Pariwisata}

Sebagai suatu daerah yang akan dikembangkan menjadi daya tarik wisata, Desa Adat Bindu memiliki potensi wisata yang terdiri dari potensi alam, budaya dan buatan manusia.

\section{2.1 Potensi Alam}

Potensi alam yang dimiliki oleh Desa Adat Bindu terdiri atas :

a. Sawah

Potensi alam yang besar dimiliki oleh Desa

Adat Bindu ialah persawahan. Luas persawahan yakni \pm 25 ha atau sekitar $50 \%$ dari luas desa. Atraksi wisata yang dapat dilakukan di persawahan diantaranya trekking, membajak sawah, menanam padi pada saat musim tanam padi dan memanen padi saat musim panen.

b. Sungai

Potensi alam lainnya yang dimiliki Desa Adat Bindu yakni sungai. Sungai ini menjadi sumber pengairan untuk persawahan. Selain itu sungai juga menjadi tempat dilakukannya atraksi wisata tubing. Pentingnya keberadaan sungai untuk kebutuhan sehari-hari membuat masyarakat selalu menjaga kebersihan sungai dengan tidak membuang sampah ke sungai dan melakukan gotong royong membersihkan sungai secara rutin.

\section{2.2 Potensi Budaya}

Potensi budaya yang terdapat di Desa Adat Bindu, antara lain :

a. Seni Tari dan Tabuh

Potensi budaya yang dimiliki Desa Adat Bindu yakni seni tari dan tabuh. Terdapat sanggar seni sebagai tempat pelatihan kesenian untuk anak-anak dan wisatawan. Sanggar tersebut dikelola oleh masyarakat lokal dan jika ada permintaan pementasan tari di hotel maka sanggar ini akan menjadi fasilitatornya.

b. Rumah Adat Bali

Potensi budaya lainnya yang ada di Desa Adat Bindu yakni rumah adat Bali. Selain dijadikan sebagai rumah tinggal bagi masyarakat lokal, rumah adat yang kosong mulai dijadikan homestay. Hal tersebut 
dapat memberikan manfaat secara langsung bagi masyarakat lokal. sejak pertama pemanfaatan rumah adat Bali menjadi homestay hanya ada sekitar 10 rumah yang disewakan namun sampai saat ini mulai banyak masyarakat lokal yang memiliki homestay dan hampir seluruh masyarakat memiliki homestay. Pemanfaatan rumah adat Bali menjadi homestay tidak hanya sebagai tempat tinggal namun wisatawan juga dapat melihat kehidupan langsung dari masyarakat lokal sehingga secara tidak langsung melihat budaya-budaya atau kebiasaan masyarakat lokal.

c. Makanan tradisional

Makanan tradisional menjadi salah satu potensi budaya yang dimiliki masyarakat Desa Adat Bindu. Wisatawan yang tinggal maupun melakukan paket wisata di Bindu akan menikmati makanan tradisional. Selain itu jika wisatawan ingin mengetahui cara memasak makanan khas Bali maka wisatawan dapat ikut serta dalam membuatnya.

d. Pura

Potensi budaya yang juga dimiliki Desa Adat Bindu yakni Pura. Wisatawan yang tinggal di Bindu dapat mengunjungi pura dan jika ada kegiatan keagamaan wisatawan dapat ikut melihatnya.

\section{2.3 Potensi Buatan Manusia}

Potensi buatan manusia yang terdapat di Desa Adat Bindu, yakni :

a. Kebun organik

Selain memiliki potensi alam dan budaya, Bindu juga memiliki potensi buatan yang salah satunya yakni kebun organik. Kebun seluas 25 are ditanami berbagai tanaman tanpa menggunakan pestisida maupun pupuk yang berbahan kimia. Kebun organik tersebut menggunakan pupuk dari daun maupun ranting pohon yang kering dan mulai membusuk. Hasil dari kebun organik biasa digunakan untuk membuat makanan atau bahan pengobatan. Penanaman di kebun organik tidak hanya dilakukan oleh Bapak Suastawa sebagai pemilik lahan namun juga melibatkan anak-anak sekolah dasar sebagai sarana pembelajaran yang bekerjasama dengan yayasan Rotary Club dan Greenschool. b. Tanah Hyang Healing Centre Bali

Potensi buatan lainnya yang ada di Bindu yakni healing centre yang bernama Tanah Hyang Healing Centre Bali. Healing Center ini telah ada sejak tahun 2009 atau 9 tahun yang lalu. Healing Centre ini dikelola oleh balian yang biasa disebut dengan Ajik Healer. Beliau merupakan penerus dari leluhurnya yang dulu menjadi Balian. Tanah Hyang Healing Centre merupakan tempat yang digunakan sebagai pengembangan wellness tourism. Tempatnya terletak di tengah persawahan dengan suasana yang sunyi jauh dari keramaian atau hiruk pikuk jalan raya. Wisatawan yang datang untuk berobat akan merasakan ketenangan jiwa. Selain terdapat bangunan yang dijadikan tempat pengobatan di tempat ini juga terdapat tempat meditasi yang menghadap ke persawahan dan kamar yang dapat digunakan wisatawan yang sedang tahap pengobatan untuk tinggal.

\section{3 Fasilitas Pendukung Pariwisata}

Mengembangkan suatu daerah menjadi daya tarik wisata harus didukung oleh ketersediaan fasilitas parwisata, antara lain :

\subsubsection{Akomodasi}

Akomodasi merupakan fasilitas pendukung yang penting untuk ada di suatu daerah pengembangan pariwisata. Di Bindu akomodasi sudah banyak ada seperti homestay yang terdapat hampir diseluruh rumah masyarakat lokal, selain itu juga terdapat beberapa villa, bungalow dan hostel. Selain itu juga terdapat hotel berbintang yang bernama Furama villas and Spa.

\subsubsection{Transportasi}

Hal penting lainnya dalam mendukung kegiatan pariwisata yakni transportasi. Di Bindu untuk kebutuhan transportasi wisatawan disediakan oleh Bindu Transport yang dikelola oleh masyarakat lokal. Bindu Transport memfasilitasi kebutuhan transport untuk wisatawan yang datang maupun keluar dari Bindu.

\section{4 Promosi Pariwisata}

Promosi menjadi satu hal yang penting dalam mengembangkan pariwisata di suatu daerah. Berbagai cara dapat dilakukan dalam mempromosikan suatu daerah agar dapat 
diketahui oleh khalayak. Untuk mempromosikan Bindu hal yang sudah dilakukan yakni mempromosikan melalui sosial media seperti facebook dan promosi lainnya yakni dari teman ke teman. Untuk promosi melalui website dilakukan pada laman www.binduvillageretreat.com.

\section{5 Peran Elit Desa}

Pariwisata menjadi aspek yang penting untuk dikelola disuatu daerah, pengelolaan yang tepat akan memberikan manfaat yang optimal maka dari itu penting adanya peran dari elit desa pariwisata.

Pada penelitian ini, pengembangan wellness tourism di Bindu masih di kelola oleh keluarga dari Gusti Suastawa sehingga yang dimaksud elit desa dalam peneltian ini yakni Gusti Suastawa dan kakak beliau yang menjadi balian yang biasa dipanggil Ajik Healer. Adanya wisata berobat di Bindu dimulai sejak 9 tahun lalu oleh Ajik Healer, beliau merupakan keturunan dari Balian yang ada di Bindu. Balian merupakan sebutan dukun di Bali atau orang yang memiliki kekuatan untuk menyembuhkan penyakit.

Pengobatan yang dilakukan dapat melalui beberapa cara tergantung kepada penyakit yang diderita dan insting beliau mengarahkan pada pengobatan yang seperti apa. Adapun jenis pengobatan yang dilakukan yakni memijat, meditasi, pembersihan dan healer. Untuk mengembangkan wisata berobat yang ada di Bindu diperlukan elit desa guna memperluas pengembangan wisata berobat yang ada di Bindu karena memiliki suasana yang berbeda dengan pengobatan lainnya.

\section{5.1 Peran Dalam Pengembangan Potensi}

Potensi wisata berobat ini diawali dengan adanya kegiatan pariwisata di kebun organik dan trekking di persawahan yang dekat dengan tempat pengobatan, mulai mengajak wisatawan untuk mengunjungi tempat pengobatan hingga akhirnya wisatawan mulai tertarik akan pengobatan tradisional tersebut hingga munculnya pemikiran untuk mengkombinasikan pengobatan tradisional tersebut dengan kegiatan pariwisata. Pengobatan tradisional dilakukan oleh balian, dengan jenis balian Usadha karena menggunakan lontar. Pengembangan pengobatan tersebut didukung oleh kepercayaan bahwa sebuah gundukan kecil yang mirip dengan bukit memiliki aura yang luar biasa untuk menyembuhkan. Selain itu wisata berobat juga didukung oleh keberadaan persawahan, budaya dari masyarakat dan tanaman obat yang dapat digunakan sebagai obat herbal. Bapak Gusti Suastawa juga menjelaskan pengembangan wellness tourism didukung oleh potensi yang ada dan dikombinasikan dengan pariwisata

"Dikoneksikan denganpariwisata itu
ide awalnya, trus kita punya
keingginan seperti itu agar mengikuti
tren sekarang orang barat tertarik
dengan pengobatan herbal, tradisional,
jadi tentang chemical dan tentang obat
kimia mereka mulai merasa takut"

Pengembangan potensi tersebut juga didukung oleh lokasi Bindu yang dekat dengan Ubud. Potensi lainnya yang dikembangkan yakni kegiatan Agni Otra atau ritual suci api unggun yang dilakukan setiap hari Purnama (bulan penuh). Kegiatan ini dipimpin oleh Rsi atau orang suci dengan didampingi oleh para pemangku dan juga diikuti oleh wisatawan. Potensi lainnya yang dapat mendukung kegiatan wellness tourism yakni pemanfaatan tanaman herbal menjadi boreh atau scrub tradisional Bali yang juga dapat dijadikan sebagai obat penyembuhan. Pemanfaatan lainnya yakni dengan alam namun tidak mengekploitasinya guna kegiatan pariwisata namun dengan kegiatan pariwisata alam akan dapat terjaga. Dengan mengajak wisatawan mengenal alam baik persawahan maupun kebun organik maka wisatawan dan masyarakat lokal akan sadar untuk menjaga lingkungan.

\section{5.2 Peran Dalam Pembangunan Fasilitas}

Pada awalnya kegiatan pengobatan dilakukan dirumah karena belum memiliki tempat khusus hingga akhirnya dibangunlah tempat untuk pengobatan yang terletak di tengah persawahan dengan suasana sunyi dan damai serta aura kesembuhan yang dapat dirasakan. Pembangunan fasilitas tersebut seperti dijelaskankan oleh Gusti Suastawa selaku pengelola 
"Kita tata lokasi segala macam karna kita punya tempat ditengah sawah. Sebenarnya lingkungan disana percaya bahwa disana punya kekuatan yang susah dijelaskan"

Pembangunan fasilitas lain yang telah dilakukan seperti penyediaan akomodasi dan transportasi. Pengembangan Bindu dengan konsep mengaburkan antara desa dengan resort yakni akomodasi dengan kelas menengah kebawah namun memiliki budaya yang kuat karena Desa Adat Bindu hanya memiliki satu pintu, budaya yang masih kuat dan segala kegiatan akan terjadi dalam kantong desa dan masyarakat lokal akan merasakan langsung dampak dari kegiatan pariwisata. Bindu dikonsepkan akan menjadi desa retreat dengan adanya aktivitas wisatawan dengan masyarakat lokal dan mengenal budaya masing-masing dan mendapat ketenangan jiwa di Desa Adat Bindu yang masih tradisional dan sunyi.

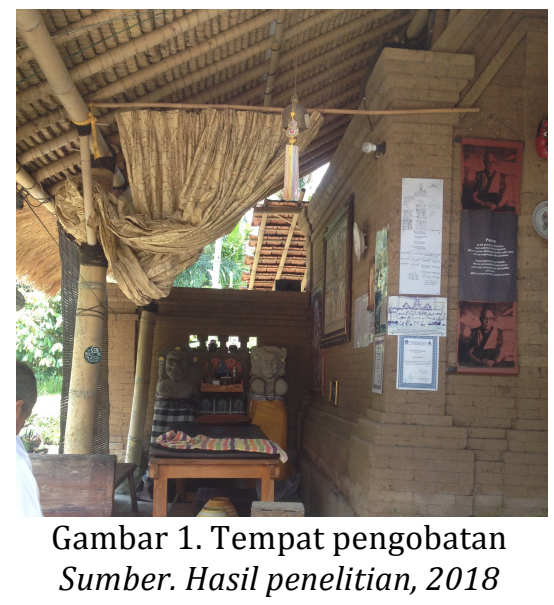

Untuk pembangunan fasilitas yang akan dilakukan yakni pembangunan bank plastik guna pengolahan sampah plastik agar sampah plastik yang awalnya hanya dianggap sampah dan dibuang sembarangan dapat diolah menjadi barang yang berguna. Selanjutnya akan dilakukan pemasangan wifi oleh Pemerintah Kabupaten Badung.

\section{5.3 Peran Dalam Promosi Pariwisata}

Promosi menjadi hal yang penting dalam pengembangan pariwisata. Elit desa mempunyai peran dalam mempromosikan daerah agar dikenal khalayak. Di Bindu upaya yang dilakukan dalam mempromosikan atraksi wisata yang ada yakni dengan melakukan promosi melalui website dan sosial media berupa facebook serta promosi langsung dari teman ke teman seperti yang dijelaskan oleh Bapak Gusti Suastawa

"Jadi punya teman orang asing kita coba untuk mengajak mereka melihat kondisi itu (wellness tourism) setelah itu mulailah teman-teman itu yang merekomendasikan kepada teman-temen mereka yang kebetulan ada disini dan orang tua dari teman anak mereka yang sekolah di green school, itulah awalnya"

Promosi yang dilakukan untuk kegiatan pengobatan hanya dilakukan melalui sosial media dan langsung dari teman ke teman. Tidak ada promosi khusus untuk kegiatan pengobatan di website karena masih bersifat donasi. Selain melakukan promosi melalui website maupun dari teman ke teman. Saat ini sedang dilakukan kerjasama dengan berbagai agen luar negeri agar Bindu lebih dikenal sebagai daya tarik wisata yang khususnya memiliki potensi wellness tourism.

Promosi wellness tourism saat ini perlu digencarkan karena Bindu yang terletak dengan Ubud dan Ubud yang saat ini sudah mulai crowded dan Bindu mempunyai potensi untuk dikembangkan sebagai daerah baru yang mengembangkan wisata berobat.

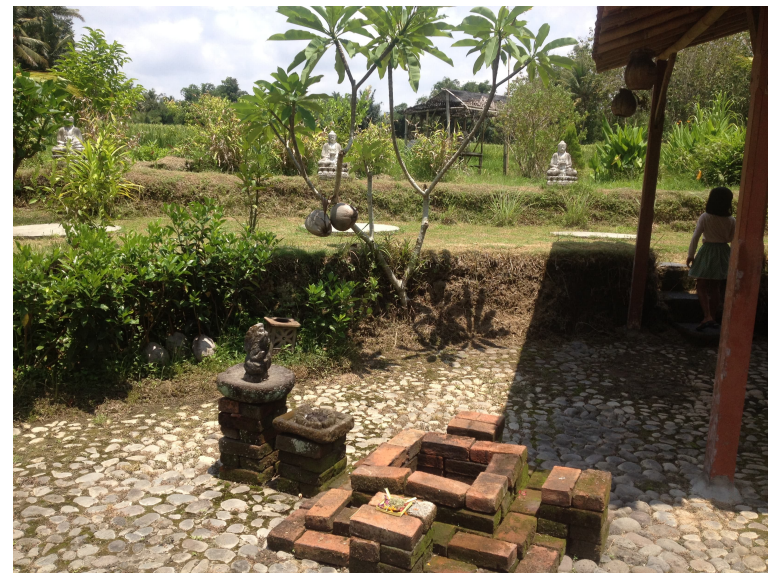

Gambar 2. Tempat meditasi Sumber. Hasil penelitian, 2018

\section{PENUTUP}

\subsection{Kesimpulan}

Dari hasil dan pembahasan penelitian diatas maka dapat disimpulkan bahwa potensi yang dimiliki Desa Adat Bindu terdiri dari potensi alam, budaya dan buatan yang dapat 
mendukung kegiatan wellness tourism di Bindu. Dengan pengembangan wellness tourism maka penting untuk dibangunnya fasilitas akomodasi dan transportasi yang saat ini sudah mulai dibangun di Bindu. Selanjutanya adapun peran dari elit desa untuk pengembangan wellness tourism, yakni: (1) Peran dalam pengembangan potensi seperti mengkemas pengobatan tradisional menjadi daya tarik wisata, diadakannya kegiatan Agni Otra, pemanfaatan bahan tradisional untuk boreh atau scrub tradisional dan melakukan pengenalan alam kepada wisatawan; (2) Peran dalam pembangunan fasilitas diantaranya yaitu pembangunan tempat pengobatan, pembangunan akomodasi dan pembangunan transportasi; (3) Peran dalam promosi pariwisata yakni melakukan promosi melalui website, sosial media dan teman ke teman serta akan dilakukan kerjasama dengan agen luar negeri.

\subsection{Saran}

Adapun saran yang diberikan kepada pengelola Tanah Hyang Healing Centre selaku elit desa pengembangan wellness tourism di Bindu yakni melakukan promosi lebih gencar agar pengembangan wellness tourism lebih banyak diketahui oleh wisatawan dan diharapkan terjalinnya kerjasama dengan pemerintah untuk pembinaan sumber daya manusia yang ada di Bindu.

\section{DAFTAR PUSTAKA}

Abu, Ahmadi, 1982, Psikologi Sosial, Surabaya: PT. Bina Ilmu.

Amalyah, Reski, Djamhur Hamid, and Luchman Hakim. 2016. Peran Elit desa Pariwisata Dalam Pengembangan Pulau Samalona Sebagai Destinasi Wisata Bahari.Jurnal Administrasi Bisnis37.1 : 158-163.

Astuty, Triana Winni. 2015. Pengaruh Elit Berkuasa Terhadap Pembangunan Desa.

Bungin, Burhan. 2007. Penelitian Kualitatif. Jakarta: Kencana.

Mosca, Gaetano. 1939. The Rulling Class. London : Hill Book Company

Paturusi, Samsul A. 2001. Perencanaan Tata Ruang Kawasan Pariwisata, Materi Kuliah Perencanaan Kawasan Pariwisata. Program Pasca Sarjana Universitas Udayana Denpasar, Bali.

Pendit, Nyoman. 1999. Ilmu Pariwisata. Jakarta: Akademi Pariwisata Trisakti.

Pramono, Jaya. 2013. Strategi Pengembangan Health and Wellness di Bali
Soekanto, Soerjono. 2002. Sosiologi : Suatu Pengantar, Jakarta : Raja Persada

Utama, , I. Gusti Bagus Rai. 2011. Health and Wellness Tourism ; Jenis dn Potensi Pengembangannya di Bali

Utama, I. Gusti Bagus Rai, and PPS Doktor Pariwisata Universitas Udayana Bali. Trend Health and Wellness Tourism in Indonesia.

Zeitlin, Irving M. 1981. Ideology and the development of sociological theory. Second Edition. Prentice-Hall 